\title{
Quantitative Analysis and Bacteriostasis of Polyphenols Extracts from Peanut Shells by Ultrahigh Pressure Extraction
}

\author{
Yali Yu ${ }^{1}$, Lijun Wang ${ }^{1}$, Feng Gao ${ }^{1, a}$, Shouqin Zhang ${ }^{2}$ \\ ${ }^{1}$ Department of Food Science and Engineering, Jilin University, Changchun, Jilin 130062, China \\ ${ }^{2}$ College of Biological and Agricultural Engineering, Jilin University, Changchun, Jilin 130062, \\ China \\ äE-mail: g_f@jlu.edu.cn, ${ }^{a}$ corresponding author.
}

\begin{abstract}
Keywords: Ultrahigh Pressure Extraction; Peanut Shells Polyphenols; Quantitative Analysis; Bacteriostasis.
\end{abstract}

\begin{abstract}
This study developed a method to extract polyphenols from peanut shells by ultrahigh pressure (PPSUP). The yield of PPSUP was up to $71.3 \mathrm{mg}$ of gallic acid equivalents (GAE) $/ \mathrm{g}$ under optimizing extraction parameters of ultrahigh pressure to $75 \%$ ethanol, $300 \mathrm{MPa}, 4 \mathrm{~min}, 1: 25$ ratio of material to liquid. The results of antibacterial activities of PPSUP showed that it had bacteriostatic action against two food-related bacteria (Escherichia coli ATCC 25922, Staphylococcus aureus ATCC 6538), which indicates it can be used as an antiseptic aid in food.
\end{abstract}

\section{Introduction}

Peanut is cultivated on a large scale, with China, India being the biggest producers ${ }^{[1]}$. Peanut kernel has a high nutritional and commercial value because of its edible oil (43 55\%). About $60 \%$ of the world's peanut kernels are used for extraction of their oil ${ }^{[2]}$. Peanut shells are abundant agricultural byproducts. Its contain many nutrients, including protein $(4 \sim 7 \%)$, fat $(1 \sim 2 \%)$, carbohydrates (10.6 21.2\%), monosaccharide, oligosaccharides, hemicellulose ${ }^{[3]}$. Peanut shells also contain some medicinal ingredients, such as luteolin, $\beta$-sitosterol, $\beta$-carotene, saponins, and xylose $^{[4]}$, as well as antioxidant ingredients, such as catechol, pyrogallol, and pyrogallic acid ${ }^{[5]}$. Therefore, research has been done for development and utilization of peanut shells in the food, chemical, and medical industries as well as agriculture and other fields ${ }^{[6]}$.

Hite pioneered research used ultrahigh hydrostatic pressure process to inactivate bacteria in milk and to denature egg albumin proteins in the late 1800s and early 1900s. Approximately 80 years later, ultrahigh pressure technique has been adapted to the specific requirements of food industry ${ }^{[7}$, ${ }^{8]}$. It offers benefits such as inactivation of microorganisms and undesirable enzymes, thereby increasing shelf life and providing safer food. Fortunately, these pressure-treated products retain more of their natural colors and flavors for less detrimental effects on food than other methods such as heat treatment ${ }^{[9]}$. Studies showed that ultrahigh pressure technique could obtain higher yields, shorten processing time, and have less negative effects on activity of bioactive components ${ }^{[10,11]}$. Recently, it had been used for extraction of lycopene from tomato paste waste, ginsenoside from Korean red ginseng, and catechins from green tea. Many efforts separated polyphenols from peanut shells using organic solvent extraction and water extraction successfully at this period. According to above discussion, this study develops a novel method extraction technique, ultrahigh pressure extraction, which can extract polyphenols from peanut shells. In addition, antibacterial activities of PPSUP against Escherichia coli ATCC 25922 and Staphylococcus aureus ATCC 6538, which commonly cause food borne disease and food spoilage.

\section{Materials and Methods}

Peanut were kept in a sealed plastic bag and stored at $4{ }^{\circ} \mathrm{C}$. Ethanol, gallic acid, Folin-Ciocalteu reagent, sodium carbonate were all purchased from the Beijing Chemical Agents Company (China). Luteolin, pyrogallol, catechol, phlorglucinol and quercetin were purchased from Sigma Company 
(United States).

A $50 \mathrm{~g}$ sample of peanut shells were defatted with $\mathrm{n}$-hexane $(3400 \mathrm{~mL})$ for $10 \mathrm{~h}$ at room temperature, and the remaining n-hexane in peanut shells was removed under reduced pressure in a vacuum oven. The defatted peanut shells were mixed with aqueous ethanol and placed into a sterile polyethylene bag. The bag was sealed after eliminating air from the inside and placed into a hydrostatic pressure vessel at room temperature under different ultrahigh pressure conditions. The experimental conditions were optimized by using orthogonal experiments.Standard curve was drawn first. Gallic acid standard solution $(100 \mu \mathrm{g} / \mathrm{mL})$ was dispensed at volumes of $0.05,0.10,0.15$, $0.20,0.25$, and 0.30 (all in $\mathrm{mL}$ ) into a $5 \mathrm{~mL}$ volumetric flask and combined with $1.95,1.90,1.85$, $1.80,1.75$, and $1.70 \mathrm{~mL}$ distilled water, respectively. The solutions were mixed for 3-4 minutes after adding extra $1 \mathrm{~mL}$ Folin-Ciocalten reagent into each flask. One milliliter of $10 \% \mathrm{Na}_{2} \mathrm{CO}_{3}$ was then added and, after shaking, put into an electric-heated thermostatic water bath $\left(25{ }^{\circ} \mathrm{C}\right)$ for $2 \mathrm{~h}$. The absorbance of the solution at $750 \mathrm{~nm}$ was then evaluated using glass cuvettes. Total phenolic content were determined with the Folin-Ciocalteu method.

Two pathogenic strains of bacteria were used in the antibacterial assay including gram-negative bacteria (Escherichia coli, ATCC 25922) and gram-positive bacteria (Staphylococcus aureus, ATCC 6538). Bacterial strains were activated by transferred from Luria broth (LB) agar medium into a test tube with sterile saline solution $(0.9 \% \mathrm{NaCl})$, and incubated at $36.5 \pm 1.0^{\circ} \mathrm{C}$ for $24 \mathrm{~h}$, resulting in an inoculum with $(4-5) \times 10^{6} \mathrm{CFU} / \mathrm{mL}$. All of these bacteria were obtained from the key laboratory of zoonosis research of Jilin University, China.

The antibacterial activity of PPSUP was measured by agar gel diffusion precipitation (AGP) method. Sterile filter paper discs $(6 \mathrm{~mm}$ diameter) were impregnated with different PPSUP concentrations $(100,1000,3000,5000 \mu \mathrm{g} / \mathrm{mL})$ for $24 \mathrm{~h}$ before testing. Then, the filter paper discs were placed on the surface of sterile agar plates which had been inoculated with $E$. coli and $S$. aureus in a biological safety hood. The plates were incubated at $36.5 \pm 1.0{ }^{\circ} \mathrm{C}$ for $24 \mathrm{~h}$, and the diameters of the clear inhibition zone were measured and reported with a verniercaliper.

MIC was determined by the two-fold dilution method. The E. coli was inculated in the LB medium at $37{ }^{\circ} \mathrm{C}$ for $24 \mathrm{~h}$. PPSUP was dissolved in $5 \%$ dimethyl sulfoxide (DMSO) and further diluted with 5\% DMSO, added to LB medium to achieve final concentrations of $0,125,250,500$, $750,1000,3000$ and $5000 \mathrm{mg} / \mathrm{mL}$. The different concentrations of PPSUP were added in the pregrown bacterial cultures, incubating at $37^{\circ} \mathrm{C}$ for $24 \mathrm{~h}$. The MIC was defined as the minimum concentrations of PPSUP at which no visible growth was observed.

\section{Results and Discussion}

The extraction yields, were defined as the ratio of polyphenols weight to sample weight. The factors that can influence yields are different solvent, pressure level, pressure holding time, liquid/solid ratio, time to achieve treatment pressure, product initial temperature, solvent concentration, and so on.
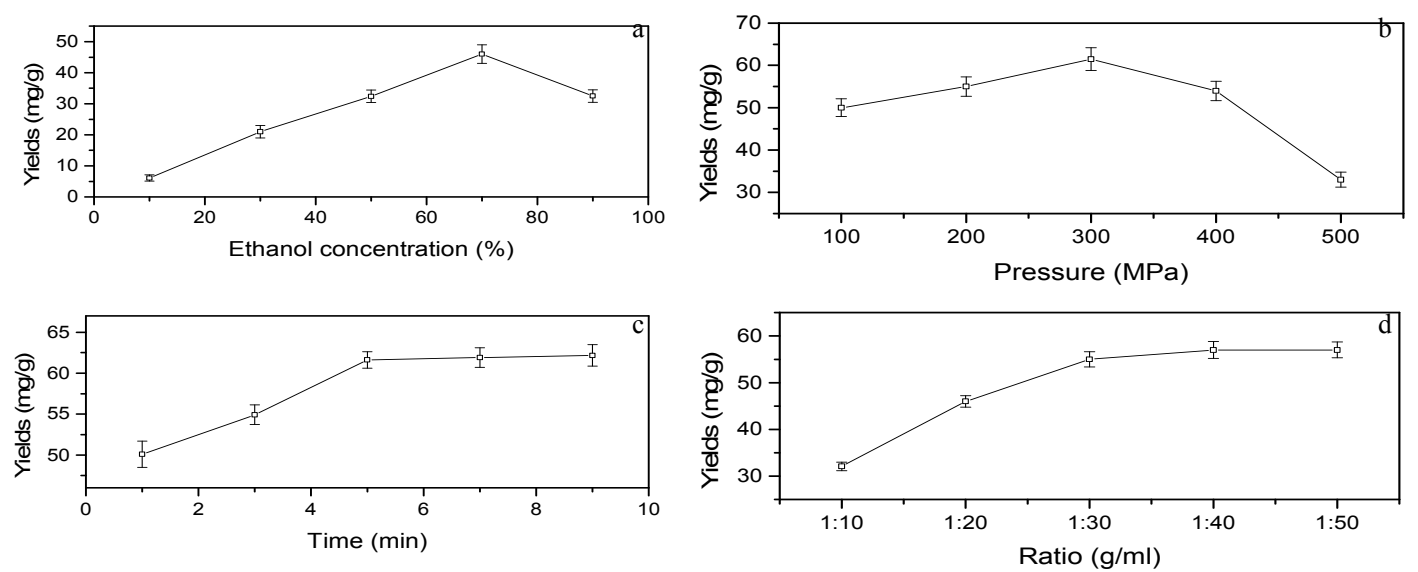

Fig.1 Effect of different factors on yields 
Fig.1 (a) illustrated the yields variation trend of PPSUP in single-factor experiments of ethanol concentration. We found that the yields increased gradually as the ethanolconcentration increased from $10 \%$ to $70 \%$, with the highest yield reached when the ethanol concentration was $70 \%$.Fig.1 (b) was the yields variation trend of PPSUP through single-factor test of ultrahigh pressure. The yields of PPSUP increased as pressure increased from $100 \mathrm{MPa}$ to $300 \mathrm{MPa}$, and the highest yield were reached at $300 \mathrm{MPa}$.Fig.1 (c) illustrated the variance of PPSUP yields in single-factor test of pressure holding time. The yields increased as the time increased from $1 \mathrm{~min}$ to $5 \mathrm{~min}$. The yields increased slightly with the time increase after $5 \mathrm{~min}$. Five-minute was selected for further orthogonal experiment.Fig.1 (d) showed the yields of PPSUP varying through single-factor test of the ratio of solids to lipids. The yields increased as the ratio of solids to lipids increased from 1:10 to 1:30. The 1:40 was selected for further orthogonal experiments based on the single-factor trend shown in Fig. 1 (d).

The extraction parameters were optimized by the orthogonal experiment method. Table 1 listed the schedule of the orthogonal experiment including four key extraction parameters: (A) ethanol concentration, (B) pressure, (C) pressure holding time, and (D) ratio.

Table 1 Extraction parameters and levels for orthogonal experiment. (a) ethanol concentration, (b) pressure lever, (c) pressure holding time, and (d) ratio of material to liquid

\begin{tabular}{ccccc}
\hline \multirow{2}{*}{ Level } & \multicolumn{4}{c}{ Extraction parameters } \\
& $\mathrm{A}(\%)$ & $\mathrm{B}(\mathrm{MPa})$ & $\mathrm{C}(\mathrm{min})$ & $\mathrm{D}(\mathrm{g} / \mathrm{ml})$ \\
\hline 1 & 65 & 250 & 4 & $1: 25$ \\
2 & 70 & 300 & 5 & $1: 30$ \\
3 & 75 & 350 & 6 & $1: 35$ \\
\hline
\end{tabular}

Detailed extraction conditions and yields of PPSUP are listed in Table 2. From the mathematical processing of the data, the yield of PPSUP under $300 \mathrm{MPa}$ pressure for $4 \mathrm{~min}$ were given the highest. Second, compared with ratio (D), the ethanol concentration (A), the pressure holding time (C), and pressure (B), showed much more significant effect on index point. So the ethanol concentration $(\mathrm{A})$, the pressure holding time $(\mathrm{C})$, and pressure lever $(\mathrm{B})$ are the primary factors that may influence the yields of PPSUP.

Table 2 Experimental conditions and yield obtained during ultrahigh pressure extraction

\begin{tabular}{cccccc}
\hline Run number & $\mathrm{A}(\%)$ & $\mathrm{B}(\mathrm{MPa})$ & $\mathrm{C}(\mathrm{min})$ & $\mathrm{D}(\mathrm{g} / \mathrm{ml})$ & Yield $(\mathrm{mg} / \mathrm{g})$ \\
\hline 1 & 1 & 1 & 1 & 3 & $58.1 \pm 1.7$ \\
2 & 1 & 2 & 2 & 2 & $61.3 \pm 1.5$ \\
3 & 1 & 3 & 3 & 1 & $64.6 \pm 1.3$ \\
4 & 2 & 1 & 2 & 1 & $66.3 \pm 1.6$ \\
5 & 2 & 2 & 3 & 3 & $70.5 \pm 1.2$ \\
6 & 2 & 3 & 1 & 2 & $68.4 \pm 1.4$ \\
7 & 3 & 1 & 3 & 2 & $69.8 \pm 1.6$ \\
8 & 3 & 2 & 1 & 1 & $71.3 \pm 1.8$ \\
9 & 3 & 3 & 2 & 3 & $65.4 \pm 1.3$ \\
\hline
\end{tabular}

For further evaluating the performance of ultrahigh pressure extraction, we compared the yields of peanut shells polyphenols through two different extraction methods, ultrahigh pressure extraction and infuse extraction. It can be found in Table 3 that yields $(71.3 \mathrm{mg} / \mathrm{g})$ of polyphenols with ultrahigh pressure extraction $(300 \mathrm{MPa})$ for $4 \mathrm{~min}$ at room temperature were higher than the yields $(56.6 \mathrm{mg} / \mathrm{g})$ of infuse extraction for $5 \mathrm{~h}$ at $75^{\circ} \mathrm{C}$. 
Table 3 Comparation of process parameters and yield of polyphenols extracted from peanut shells by different methods

\begin{tabular}{cccccccc}
\hline $\begin{array}{c}\text { Extract } \\
\text { method }\end{array}$ & $\begin{array}{c}\text { Ethanol } \\
\text { concentration } \\
(\%)\end{array}$ & $\begin{array}{c}\text { Pressure } \\
\text { level } \\
(\mathrm{MPa})\end{array}$ & $\begin{array}{c}\text { Temperature } \\
\left({ }^{\circ} \mathrm{C}\right)\end{array}$ & $\begin{array}{c}\text { Power } \\
(\mathrm{w})\end{array}$ & $\begin{array}{c}\text { Time } \\
\text { matio of } \\
\text { liquid } \\
(\mathrm{g} / \mathrm{ml})\end{array}$ & $\begin{array}{c}\text { Yield } \\
(\mathrm{mg} / \mathrm{g})\end{array}$ \\
\hline $\begin{array}{c}\text { Infuse } \\
\text { pressure }\end{array}$ & 65 & - & 75 & - & $5 \mathrm{~h}$ & $1: 30$ & 56.6 \\
\hline
\end{tabular}

Results in this paper indicated that the yield of phenols was $71.3 \mathrm{mg}$ of gallic acid equivalents (GAE) /g of shells under the optimized conditions (75\% ethanol-water solution, $300 \mathrm{MPa}, 4 \mathrm{~min}$, $1: 25$ ration of solid to liquid). The maximum yield of total phenols was found to be $118 \mathrm{mg}$ of gallic acid equivalents (GAE) /g of shells under the optimized conditions $(30.8 \%$ ethanol-water solution, $\left.30.9^{\circ} \mathrm{C}, 12 \mathrm{~min}\right)$.

PPSUP showed significant antibacterial activity against the two food-related bacteria (E. coli ATCC 25922, S. aureus ATCC 6538) from the data lined in Table 4. Growth inhibition zones of PPSUP with $5000 \mu \mathrm{g} / \mathrm{ml}$ resulted in $9.00,9.50 \mathrm{~mm}$ for E.coli, S.aureus, respectively, while in infuse method sample, with $5000 \mu \mathrm{g} / \mathrm{ml}$, these were $8.12,8.45 \mathrm{~mm}$. These results indicated that the PPSUP samples showed a higher anti-microbial activity than the sample obtained by infuse method.

Table 4 Diameter of inhibition zone and Minimum inhibitory concentrations (MIC) of polyphenols

\begin{tabular}{|c|c|c|c|c|c|c|c|c|c|c|}
\hline \multirow{3}{*}{ Strains } & \multicolumn{8}{|c|}{ Diameter of inhibition zone $(\mathrm{mm})$} & \multicolumn{2}{|c|}{$\operatorname{MIC}(\mu \mathrm{g} / \mathrm{ml})$} \\
\hline & \multicolumn{5}{|c|}{ Infuse $(\mu \mathrm{g} / \mathrm{ml})$} & \multicolumn{3}{|c|}{ Ultrahigh pressure $(\mu \mathrm{g} / \mathrm{ml})$} & \multirow{2}{*}{$\begin{array}{l}\text { Infuse } \\
(\mu \mathrm{g} / \mathrm{ml} \\
)\end{array}$} & \multirow{2}{*}{$\begin{array}{l}\text { Ultrahigh } \\
\text { pressure } \\
(\mu \mathrm{g} / \mathrm{ml})\end{array}$} \\
\hline & 100 & 1000 & 3000 & 5000 & 100 & 1000 & 3000 & 5000 & & \\
\hline $\begin{array}{c}\text { E. coli } \\
\text { (ATCC 25922) }\end{array}$ & $6.12 \pm 0.15^{\mathrm{a}}$ & $6.95 \pm 0.13$ & $7.96 \pm 0.21$ & $8.12 \pm 0.23$ & $6.69 \pm 0.31^{\mathrm{a}}$ & $7.75 \pm 0.15$ & $8.65 \pm 0.20$ & $\begin{array}{c}9.00 \pm 0.1 \\
8\end{array}$ & 200 & 100 \\
\hline $\begin{array}{c}\text { S. aureus } \\
\text { (ATCC 6538) }\end{array}$ & $6.23 \pm 0.19$ & $6.97 \pm 0.22$ & $8.01 \pm 0.11$ & $8.45 \pm 0.14$ & $7.13 \pm 0.19$ & $7.56 \pm 0.35$ & $8.75 \pm 0.22$ & $\begin{array}{c}9.50 \pm 0.1 \\
9\end{array}$ & 200 & 100 \\
\hline
\end{tabular}

\section{Conclusions}

Ultrahigh pressure extraction is founded to extract polyphenols from peanut shells. In the investigated ranges of ethanol concentration, pressure, time, ratio, the optimized conditions of PPSUP are: $75 \%$ ethanol solution as solvent, $300 \mathrm{MPa}$ for pressure, 4-min pressure holding time, 1:25 of liquid to solid. Comparing with infuse extraction, ultrahigh pressure extraction has excellent advantages, such as shorter extraction time, higher yield, lower energy consumption, eco-friendly and so on. In antibacterial activities test, results showed that a low concentration of PPSUP could inhibit the growth of E. coli and S. aureus, indicating it could be used as an antiseptic aid in food.

\section{Acknowledgements}

The authors wish to thank the China Scholarship Council and the Science and Technology Department of Jilin Province (20140201018NY), China, for financial support of this research.

\section{References}

[1] Stalker, H. T. Peanut (Arachis hypogaea L.). Field. Crop. Res., 1997, 53, 205-217. 
[2] Wang, J., Yuan, X.P., Jin, Z.Y., Tian, Y., Song, H.L. Free radical and reactive oxygen species scavenging activities of peanut skins extract. Food. Chem., 2007, 104, 242-250.

[3] Wang, J., Wang, Y.D., Yang, X.L., Yu, Y.L. Hot infuse Extraction of polyphenol from peanut shell. Academ. Perio. Farm Prod. Proc., 2008, 4, 70-73.

[4] Sobolev, V. C., Cole, R. J. Note on utilization of peanut seed testa. J. Sci. Food. Agr., 2003, 84, 105-111.

[5] Lou, H., Yuan, H., Yamazaki, Y., Sasaki, T., \& Oka, S. Alkaloids and flavonoids from peanut skins. Planta. Med., 2001, 67, 345-349.

[6] Duh, P. D., Yeh, D. B., Yen, G. C. Extraction and identification of an antioxidative component from peanut hulls. J. Am. Oil. Chem. Soc., 1992, 69, 814-818.

[7] Hite, B. H. The effect of pressure in the preservation of milk. Washington, Va. University, Agriculture Experiment Station, Bulletin, 1899, 58, 15-35.

[8] Zimmerman, F., \& Bergman, C. Isostatic high-pressure equipment for food preservation. Food. Tech., 1993, 47(6), 162-166.

[9] Corrales, M., Toepfl, S., Butz, P., Knorr, D., Tauscher, B. Extraction of anthocyaninsfrom grape by-products assisted by ultrasonics, high hydrostatic pressure or pulsed electric fields: a comparison. Innov. Food. Sci. Emerg., 2008, 9, 85-91.

[10] Knorr, D. Effects of high hydrostatic pressure processes on food safety and quality. Food. Tech., 1993, 47, 156-161.

[11] Sánchez-Moreno, L. Plaza, B.de. Ancos, Cano, M.P. Effect of combined treatments of high pressure and natural additives on carotenoid extract ability and antioxidant activity of tomato puree (Lycopersicum esculentum Mill.). Eur. Food Res. Technol., 2004, 219, 151-160. 